\title{
PROSPEK PENGEMBANGAN INDUSTRI HILIR PENGOLAHAN KARET DI PROVINSI JAMBI
}

\author{
Downstream Rubber Industry Development In Jambi Province
}

Dompak MT NAPITUPULU, Zulkifli ALAMSYAH, dan ELWAMENDRI

Jurusan Agribisnis Fakultas Pertanian Universitas Jambi

Email : dompakn@yahoo.com

Diterima : 27 November 2013 / Direvisi : 20 Februari 2014 / Disetujui : 20 Mei 2014

\begin{abstract}
Rubber trees have been grown at smallholder level for more than 100 years in Jambi. Natural rubber is also treated as a major commodity for its large constribution to the government earnings. Nevertheless, the impact on the farmer's income seems insignificant. This research aimed to identify farmer perception in developing natural rubber based industry as well as identify strategic environmental factor affecting the downstream agroindustry development in Jambi. The research was undertaken in three natural rubber estates in the regencies of Muaro Jambi, Sarolangun, and Bungo. Data were collected by survey method and analysed with descriptive method. Strategy of downstream rubber industry was approached by SWOT, while feasibility to develop the industry was analyzed by cash flow. The results showed that $78.33 \%$ of respondent accepted the rubber industry development in their locations. In addition, it was identified that at least two strength, three weakness, three opportunities and two threatening factors could affect the natural rubber based agroindustry development in Jambi.
\end{abstract}

Keywords: Latex, agroindustry, SWOT, strategy, financial analysis

\footnotetext{
Abstrak

Karet alam telah diusahakan pada tingkat perkebunan karet rakyat di Provinsi Jambi sejak lebih dari seratus tahun yang lalu. Kontribusinya yang cukup besar terhadap perekonomian daerah menyebabkan karet alam dianggap sebagai salah satu komoditas unggulan Provinsi Jambi. Namun kontribusinya dalam meningkatkan kesejahteraan masyarakat khususnya petani produsen belum terlihat nyata. Penelitian ini ditujukan untuk mengidentifikasi persepsi petani karet rakyat terhadap pengembangan industri berbahan baku karet secara lokal dan mengidentifikasi faktor-faktor lingkungan strategis yang dapat mempengaruhi pengembangan industri hilir pengolahan karet alam di Provinsi Jambi. Penelitian ini dilakukan di tiga kabupaten sentra produksi karet alam di
}

Provinsi Jambi yakni di Kabupaten Muaro Jambi, Bungo dan Sarolangun. Data dihimpun dengan metode survei dan dianalisis dengan menggunakan metode analisis deskriptif. Strategi pengembangan usaha didekati dengan metode analisis SWOT, sementara kelayakan pengembangan usaha dianalisis dengan menggunakan analisis arus dana (cash flow). Hasil analisis menunjukkan bahwa upaya pengembangan industri hilir berbahan baku karet alam direspons dengan sangat baik oleh petani karet rakyat. Pada umumnya $(78,33 \%)$ responden setuju jika industri hilir pengolahan karet alam dikembangkan di lokasi penelitian. Hasil analisis lingkungan strategis menunjukkan terdapat dua faktor kekuatan, tiga faktor kelemahan, tiga faktor peluang dan dua faktor ancaman yang dapat mempengaruhi keberhasilan pengembangan industri pengolahan lateks pekat di lokasi penelitian.

Kata kunci: Lateks, agroindustri, SWOT, strategi, analisis finansial

\section{PENDAHULUAN}

Karet alam merupakan salah satu komoditas unggulan Provinsi Jambi yang telah diusahakan pada tingkat perkebunan karet rakyat sejak lebih dari seratus tahun yang lalu. Hingga dewasa ini, kontribusi komoditas ini terhadap perolehan pendapatan daerah masih tergolong signifikan. Hal ini ditandai dengan kontribusinya terhadap Produk Domestik Regional Bruto (PDRB) yang masih relatif besar dibandingkan dengan komoditas pertanian lainnya. Data statistik menunjukkan bahwa komoditas karet berperan sebagai penyumbang devisa yang cukup berarti terhadap perekonomian Provinsi Jambi. Pada tahun 2007 Provinsi Jambi tercatat mengekspor karet sejumlah 204.534 ton dengan nilai devisa sebesar US \$ 412.230.000. Pada tahun 2011, komoditas 
karet menjadi kontributor utama terhadap perolehan devisa negara dari Provinsi Jambi yakni dengan total ekspor 238.965 ton dengan total perolehan devisa sebesar US \$ 1.111 .721 .556 (BPS, 2012). Namun demikian, peran usaha tani karet dalam meningkatkan kesejahteraan masyarakat cenderung semakin melemah. Kualitas bahan olahan karet (BOKAR) kering yang dihasilkan oleh petani juga semakin rendah. Alamsyah et al (2010), mengatakan bahwa rata-rata pendapatan petani karet rakyat di Provinsi Jambi tahun 2008 sebesar Rp 6.090.573/KK/tahun lebih rendah dari Standar Millennium Development Goals (MDGs). Fenomena tersebut ditengarai dapat terjadi disebabkan oleh daya tawar petani karet rakyat yang lemah dalam tataniaga karet alam.

Sistem pemasaran BOKAR yang telah terbangun sejak lama dan telah membudaya ditengarai menjadi salah satu penyebab semakin rendahnya mutu bahan olah karet yang dihasilkan oleh petani karet rakyat di berbagai daerah di Provinsi Jambi. Untuk mengembalikan kejayaan karet alam nasional pada umumnya dan daerah pada khususnya maka perlu dikaji pola penanganan pasca panen dan pemasaran yang dapat mengarahkan pada peningkatan kualitas bahan olah karet yang dihasilkan oleh petani dan sekaligus peningkatan pendapatan petani karet rakyat. Permasalahan yang hendak dikaji dalam penelitian ini adalah:

a) Bagaimana persepsi petani karet rakyat terhadap upaya peningkatan nilai tambah karet alam melalui pengenalan industri hilir berbahan baku karet alam di tingkat petani?

b) Apakah industri hilir berbahan baku karet alam layak dikembangkan di tingkat petani di Provinsi Jambi ?

Oleh karena itu, penelitian ini bertujuan untuk mengidentifikasi persepsi petani karet rakyat terhadap pengembangan industri berbahan baku karet secara lokal dan mengidentifikasi faktor-faktor lingkungan strategis yang dapat mempengaruhi pengembangan industri hilir karet alam di Provinsi Jambi. Melalui pengembangan industri penghasil lateks pekat ditingkat petani, mutu bahan olah karet dan pendapatan petani karet dapat ditingkatkan. Hal ini senada dengan pendapat Saleh (1991) dan Evawani (2011) dimana peningkatan daya saing bahan olah karet rakyat (BOKAR) dewasa ini masih sangat terbuka untuk dilakukan.

\section{BAHAN DAN METODE}

Penelitian dilakukan di tiga kabupaten sentra produksi karet alam di Provinsi Jambi yakni di Kabupaten Muaro Jambi, Bungo dan Sarolangun. Data primer diperoleh melalui wawancara dengan petani yang mengusahakan kebun karet serta melalui kegiatan fokus grup diskusi (FGD) yang menyertakan para pemangku kepentingan di lingkungan industri perkaretan. Guna melengkapi data primer, sejumlah data sekunder juga dihimpun dari instansi pemerintah dan swasta yang bergerak di bidang pembangunan ekonomi karet. Data yang dihimpun kemudian dianalisis dengan menggunakan metode analisis deskriptif. Strategi pengembangan usaha industri pengolahan lateks pekat didekati dengan metode analisis SWOT, sementara kelayakan pengembangan usaha dianalisis dengan menggunakan analisis arus dana (cashflow).

\section{HASIL DAN PEMBAHASAN}

\section{Gambaran Umum Karet Alam Provinsi Jambi}

Data menunjukkan bahwa luas tamanan karet di Provinsi Jambi sampai dengan tahun 2011 telah mencapai 653 ribu hektar, meningkat sebesar 16,39\% dibandingkan tahun 2002, atau rata-rata meningkat sebesar $1 \%$ per tahun. Berdasarkan wilayah sebarannya, komoditas karet dapat ditemui pada seluruh wilayah kabupaten/kota, kecuali Kota Kerinci, di Provinsi Jambi meskipun dengan tingkat kepadatan yang bervariasi. Namun demikian, seiring dengan pola pengembangan usaha tani karet yang mayoritas diusahakan oleh petani karet rakyat, terdapat sejumlah besar $(17,87 \%)$ usaha perkebunan yang berada dalam kondisi karet tua atau rusak dan 29,24\% tanaman karet belum menghasilkan sisanya $52,87 \%$ merupakan tanaman karet menghasilkan (Disbun Provinsi Jambi, 2012). 
Data Perkebunan Provinsi Jambi juga menunjukkan bahwa produksi bahan olah karet daerah ini pada tahun 2011 adalah sebesar 320 ribu ton dengan produktivitas rata-rata sebesar 856 $\mathrm{kg} / \mathrm{ha} /$ tahun. Umumnya produksi bahan olah karet yang dihasilkan oleh petani di Provinsi Jambi adalah berbentuk slab tebal dengan ketebalan 20 sampai $40 \mathrm{~cm}$. Hasil penelitian juga menunjukkan bahwa meskipun relatif banyak petani yang mengetahui cara menerapkan teknologi pasca panen karet yang baik, akan tetapi masih banyak juga petani yang tidak menerapkannya. Hal ini juga sesuai dengan temuan Suharyono (2006) yang mengatakan bahwa pola penanganan pasca panen yang dilakukan oleh petani karet di Jambi telah diwarisi dari orang tua mereka. Hasil penelitian juga menunjukkan bahwa sekitar 81,67 persen petani masih menggunakan kotoran dalam proses pengolahan bokar yang dihasilkan. Berbagai kondisi perkebunan karet Provinsi Jambi yang kurang kondusif yang bermuara pada rendahnya kualitas dan kuantitas bokar yang dihasilkan meyebabkan pemerintah daerah meluncurkan Program Replanting Karet Provinsi Jambi. Di samping itu Pemerintah Daerah dengan motto Jambi Emas telah mencanangkan akan mendirikan 17 industri pengolahan kompon karet hingga tahun 2014.

\section{Agroindustri Berbahan Baku Lateks Kebun}

Untuk memperoleh gambaran awal pengembangan industri hilir berbahan baku karet alam yang layak dikembangkan di wilayah Provinsi Jambi, maka tim peneliti melakukan studi banding ke Provinsi Sumatera Selatan dan Jawa Barat. Badan Penelitan Pengembangan dan Inovasi Daerah (Balitbangnovda) Provinsi Sumatera Selatan bekerja sama dengan Kementerian Riset dan Teknologi (Ristek) telah mengintroduksikan teknologi Industri Rumah Tangga berbahan baku karet alam (lateks pekat) untuk menghasilkan berbagai souvenir dan kebutuhan rumah tangga. Salah satu upaya yang sedang dilakukan dewasa ini adalah pendirian Inkubator Teknologi Balitbangnovda Provinsi Sumatera Selatan di Kelurahan Talang Jambe, Palembang. Inkubator Teknologi Balitbangnovda Sumatera Selatan di Kelurahan Talang Jambe menghasilkan berbagai produk kebutuhan rumah tangga seperti sandal, topi, tikar, dan jok dari serat sabut kelapa berkaret. Agroindustri sebutret (serat sabut kelapa berkaret) pada dasarnya merupakan agroindustri yang tidak membutuhkan penguasaan teknologi yang terlalu canggih sehingga dianggap sangat layak untuk dikembangkan pada tingkat industri rumah tangga atau kelompok tani (Intan et al., 2004).

Pembuatan sebutret meskipun melalui sejumlah proses namun secara teknis tidak membutuhkan tingkat keahlian yang terlalu spesifik. Alur teknis pembuatan sebutret telah dipublikasi oleh BPTK Bogor (2003) yang menunjukkan bahwa pembuatan serat sabut kelapa berkaret secara umum meliputi proses pengolahan sabut kelapa menjadi serat keriting, pengolahan dispersi bahan kimia karet, pengolahan lateks dan pembuatan sebutret yang secara sederhana dapat diuraikan sebagai berikut:

a) Pengolahan sabut kelapa menjadi serat keriting. Pada tahap ini kulit kelapa yang telah dikeringkan digiling dengan menggunakan mesin pemecah sabut untuk diambil seratnya. Selanjutnya serat gilingan tersebut dipisahkan antara serat kasar dan serat halus. Setelah dipisah, serat kasar digiling ulang, sedangkan serat halus dikeritingkan. Hasil pintalan serat dioven selama 4 jam dalam suhu $80^{\circ} \mathrm{C}$ atau dijemur di bawah sinar matahari selama beberapa hari sampai serat tersebut kering. Setelah dioven, pintalan yang telah dikeringkan diperam selama sehari semalam untuk selanjutnya diurai kembali untuk menjadi serat keriting. Adapun proses pembuatan serat keriting sabut kelapa ini disajikan pada Gambar 1.

b) Proses pengolahan dispersi bahan kimia karet. Pembuatan bahan dispersi diawali dengan penimbangan bahan kimia sesuai formula yang telah ditentukan. Selanjutnya campuran berbagai bahan kimia yang telah dilarutkan dan atau diencerkan dengan air tersebut dimasukkan ke dalam guci keramik berpeluru, perlu diperhatikan agar menyediakan tempat kosong untuk udara setidaknya satu per tiga bagian dari guci, dan selanjutnya diputar selama 24 jam pada mesin pengocok (ball mill). 


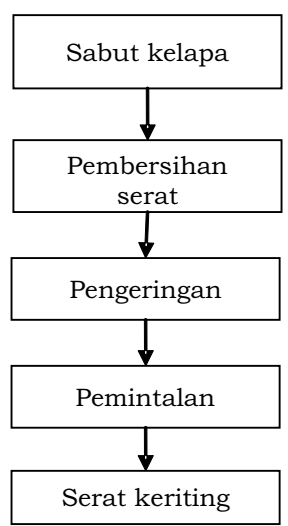

Gambar 1. Alur kerja pembuatan serat keriting

Figure 1. Manufacturing curly coconut fiber flow chart

Kemudian larutan bahan kimia yang telah melalui proses dispersi tersebut siap digunakan untuk proses pengolahan lateks karet alam.

c) Proses pengolahan lateks menjadi kompon. Setelah proses pembuatan dispersi bahan kimia selesai, lateks yang akan dibuat menjadi kompon mulai dapat disiapkan. Lateks terlebih dahulu disaring untuk memisahkan kotoran yang tercampur pada saat penyadapan dan pengumpulan. Selanjutnya larutan bahan kimia hasil dispersi dimasukkan ke dalam lateks, diaduk dengan kecepatan rendah selama lebih kurang 1-2 jam. Kemudian dimasukkan larutan texapon dengan tetap diaduk selama 5-10 menit, yang diikuti dengan larutan $\mathrm{KOH}$ dengan lateks tetap diaduk selama 5-10 menit. Setelah itu kompon diperam sesuai kebutuhan (hingga gelembung udara yang terbentuk dari hasil pengadukan hilang). d) Proses pembuatan serat sabut kelapa berkaret. Pembuatan serat sabut kelapa berkaret dilakukan dengan membungkus serat sabut kelapa keriting dengan cairan kompon lateks. Pembungkusan serat keriting dilakukan dengan cara pendadaran serat dalam bentuk lapisan tipis dalam wadah cetakan untuk kemudian disemprot dengan larutan kompon cair yang telah dihasilkan sebelumnya. Penyemprotan dilakukan beberapa tahap, dimana penyemprotan tahap pertama ditujukan untuk menyatukan setiap serat sehingga terbentuk lembaran sebutret tipis. Agar keutuhan lembaran serat dapat lebih baik, maka dilakukan penyemprotan tahap kedua. Untuk memperoleh lembaran sebutret yang lebih tebal, sejumlah lembaran sebutret tipis ditumpuk dengan arah yang berbeda untuk selanjutnya dikempa dan divulkanisasi dalam oven dengan suhu $100-110^{\circ} \mathrm{C}$ selama kurang lebih 60-75

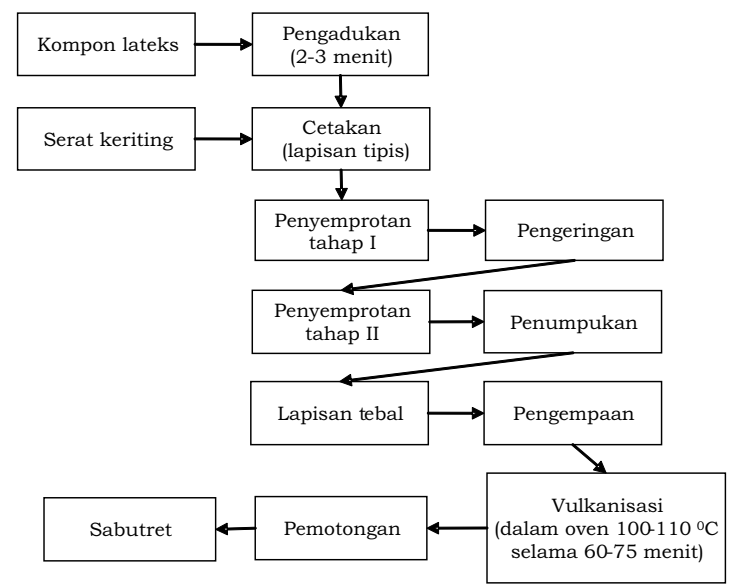

Gambar 2. Alur kerja pembuatan produk serat sabut kelapa berkaret Figure 2. Manufacturing rubberised coconut fiber (sebutret) flow chart 
menit. Adapun alur proses pembuatan sebutret disajikan pada Gambar 2 .

Berdasarkan hasil studi banding tersebut, dapat dikatakan bahwa salah satu upaya peningkatan nilai tambah karet alam pada tingkat petani produsen adalah mendirikan usaha pengolahan berbahan baku lateks cair.

\section{Persepsi Petani}

Upaya pengembangan industri hilir berbahan baku karet alam direspon dengan sangat baik oleh petani karet rakyat. Hasil analisis data menunjukkan bahwa umumnya $(78,33 \%)$ responden setuju jika terdapat investor atau lembaga yang bersedia mendirikan industri hilir pengolahan karet alam di lokasi petani. Sejumlah $62,00 \%$ responden menyatakan bahwa bahan baku lateks kebun akan dapat dengan mudah diperoleh jika industri pengolahan karet alam didirikan di lokasi penelitian. Lebih lanjut, sejumlah $60 \%$ diantara responden menyatakan bersedia mengalihkan hasil produksi mereka dari bahan olahan karet kering (bokar) menjadi lateks kebun jika memang ada pasar yang membutuhkannya. Kejenuhan petani dan hilangnya kepercayaan mereka atas kejujuran pedagang pada berbagai tingkat tataniaga karet yang mereka hasilkan menyebabkan petani cenderung mengurangi mutu bokar yang mereka hasilkan.
Upaya pengembangan industri hilir berbahan baku karet alam dapat dipengaruhi oleh sejumlah faktor sebagaimana disajikan pada Tabel 1 . Pada Tabel 1 dapat dilihat bahwa berdasarkan persepsi petani, faktor ketersediaan modal menjadi faktor utama dalam menentukan keberhasilan pengembangan usaha industri berbahan baku karet di tingkat petani. Data hasil penelitian menunjukkan bahwa $83,33 \%$ dan $16,67 \%$ dari responden memiliki anggapan bahwa modal adalah komponen utama yang keberadaannya tergolong sangat penting dan penting dalam upaya pengembangan industri hilir berbahan baku karet di Provinsi Jambi.

Ketersediaan modal menjadi sangat menentukan mengingat hingga dewasa ini kelembagaan kelompok tani ataupun gabungan kelompok tani dirasakan belum memiliki modal yang memadai untuk mendirikan industri pengolahan hasil berbahan baku karet. Disamping itu dapat dengan nyata dijumpai bahkan di berbagai penelitian bahwa hilangnya daya tawar petani dalam transaksi jual beli karet lebih sering disebabkan ketergantungan petani kepada pembeli (toke) untuk memperoleh sejumlah dana (Junaidi, 2009; Napitupulu, 2011). Modal yang dibutuhkan dengan demikian bukan saja terbatas pada biaya investasi pendirian tetapi biaya operasional termasuk biaya pengadaan bahan baku dari petani.

Tabel 1. Faktor yang mempengaruhi keberhasilan pendirian industri hilir berbahan baku karet berdasarkan persepsi responden

Table 1. Factors affecting downstream rubber industry establishment based on the respondents' perception

\begin{tabular}{clc}
\hline & \multicolumn{1}{c}{$\begin{array}{c}\text { Komponen } \\
\text { Components }\end{array}$} & $\begin{array}{c}\text { Bobot kepentingan } \\
\text { Importance level }\end{array}$ \\
\hline a) & Ketersediaan modal & 3,833 \\
b) & Manfaatnya bagi masyarakat sekitar & 3,667 \\
c) & Kemampuannya dalam menyerap tenaga kerja lokal & 3,600 \\
d) & Ketersediaan bahan baku & 3,317 \\
e) & Sistem transaksi (mutu, harga, dan pembayaran) bahan baku & 3,217 \\
f) & Jenis input yang dibutuhkan & 2,967 \\
g) & Jenis output yang akan dihasilkan & 2,950 \\
\hline
\end{tabular}

Sumber: analisis data primer (Source : prime data analysis)

Keterangan: Skor bobot kepentingan (Remaks : importance level score) :

$1=$ tidak penting (unimportant) $3=$ penting (important)

$2=$ kurang penting (less important) $\quad 4=$ sangat penting (very important) 


\section{Analisis Lingkungan Strategis}

Analisis lingkungan strategis menunjukkan sejumlah faktor penentu keberhasilan pengembangan industri pengolah lateks pekat di lokasi penelitian adalah penyediaan bahan baku, kesiapan pelaku usaha, terbatasnya dana dan penumpukan modal, rendahnya tingkat produktivitas bokar, rendahnya kualitas bokar, dukungan kebijakan pemerintah dan pemerintah daerah, komitmen pemerintah dan perbankan dalam penyediaan dana dengan biaya yang rendah, terbukanya peluang pasar, kuatnya keterikatan antara petani dan tengkulak, dan kekuatan oligopsoni para pedagang besar (pemasok industri crumb rubber).

Hasil identifikasi faktor-faktor SWOT di atas menggambarkan secara jelas bagaimana ancaman dan kelemahan yang dihadapi dalam pengembangan industri hilir karet di Provinsi Jambi. Dari gambaran tersebut, hal yang paling penting dalam analisis ini adalah memformulasikan strategi yang harus dilaksanakan mengatasi ancaman dan kelemahan tersebut dengan menggunakan peluang dan kekuatan yang ada. Dalam bentuk matriks perumusan strategi tersebut dirinci menurut sel-sel yang terbentuk dari setiap elemen SWOT tersebut yaitu strategi SO (Kekuatan-Peluang), strategi ST (KekuatanAncaman), strategi WO (KelemahanPeluang), dan strategi WT (KelemahanAncaman) sebagaimana di sajikan pada Tabel 2.

Pada Tabel 2 disajikan matrik hasil elaborasi sejumlah komponen internal dan eksternal agroindustri berbahan baku lateks kebun jika dikembangkan di tingkat petani di wilayah penelitian. Sejumlah komponen internal dan eksternal tersebut diperoleh dari elaborasi data primer yang selanjutnya kebenarannya di cross-check melalui kegiatan FGD yang dilakukan kemudian. Sesuai dengan sajian yang dilakukan terlebih dahulu, terdapat dua faktor yang diprediksi menjadi komponen kekuatan yang dimiliki agro industri tersebut jika ditumbuhkan di tingkat petani yakni faktor ketersediaan bahan baku dan kesiapan kelompok tani sebagai pelaku usaha. Selain dua kekuatan tersebut, juga dielaborasi tiga elemen yang masih menjadi kelemahan agro industri yakni terbatasnya dana dan penumpukan modal, rendahnya tingkat produktivitas bokar serta rendahnya kualitas bokar yang dihasilkan petani dewasa ini.

Tabel 2. Matriks strategi berdasarkan elemen SWOT dalam pengembangan industri hilir pengolahan karet di Provinsi Jambi

Table 2. Strategy matrix based on SWOT elements on downstream rubber industry in Jambi Province

\begin{tabular}{|c|c|c|}
\hline $\begin{array}{l}\text { Elemen SWOT } \\
\text { SWOT's element }\end{array}$ & $\begin{array}{l}\text { Kekuatan (Strenght) : } \\
\text { Ketersediaan bahan baku } \\
\text { Kesiapan pelaku usaha/ Indutri } \\
\text { rumah tangga }\end{array}$ & $\begin{array}{l}\text { Kelemahan (Weakness): } \\
\text { Terbatasnya dana dan } \\
\text { penumpukan modal } \\
\text { Rendahnya tingkat produktivitas } \\
\text { bokar } \\
\text { Rendahnya kualitas bokar }\end{array}$ \\
\hline $\begin{array}{l}\text { Peluang (Opportunity): } \\
\text { Dukungan kebijakan Pemerintah dan } \\
\text { Pemerintah Daerah } \\
\text { Komitmen Pemerintah dan } \\
\text { perbankan dalam penyediaan dana } \\
\text { dengan biaya yang rendah } \\
\text { Terbukanya peluang pasar }\end{array}$ & $\begin{array}{l}\text { Strategi SO: } \\
\text { Penyusunan roadmap pengembangan } \\
\text { industri hilir karet skala rumah } \\
\text { tangga } \\
\text { Penyusunan model klaster } \\
\text { pengembangan industri hilir karet. } \\
\text { Membangun industri hilir karet } \\
\text { sebagai model pengembangan. }\end{array}$ & $\begin{array}{l}\text { Strategi WO: } \\
\text { Membangun skim kredit yang } \\
\text { mendukung pengembangan } \\
\text { industri hilir karet } \\
\text { Pembinaan petani dalam } \\
\text { peningkatan teknik budidaya dan } \\
\text { penerapan pasca panen yang lebih } \\
\text { efisien. }\end{array}$ \\
\hline $\begin{array}{l}\text { Ancaman (Threat): } \\
\text { Kuatnya keterikatan antara petani } \\
\text { dan tengkulak } \\
\text { Kekuatan oligopsoni para pedagang } \\
\text { besar (pemasok industri crumb } \\
\text { rubber) }\end{array}$ & $\begin{array}{l}\text { Strategi ST: } \\
\text { Membangun jaringan kerjasama yang } \\
\text { kuat antar pelaku usaha dalam } \\
\text { bentuk model klaster industri. }\end{array}$ & $\begin{array}{l}\text { Strategi WT: } \\
\text { Membangun kelembagaan } \\
\text { keuangan mikro atau BUMD yang } \\
\text { dapat berperan menggantikan } \\
\text { peran tengkulak/pedagang besar. }\end{array}$ \\
\hline
\end{tabular}


Berdasarkan matriks elemen SWOT di atas maka dapat dirumuskan beberapa alternatif strategi yang perlu ditindaklanjuti dalam upaya pengembangan industri hilir karet di Provinsi Jambi. Secara rinci strategi tersebut dapat diuraikan sebagai berikut:

a) Penyusunan roadmap pengembangan industri hilir karet skala rumah tangga di Provinsi Jambi.

b) Penyusunan model klaster pengembangan industri hilir karet.

c) Membangun industri hilir karet sebagai model pengembangan.

d) Membangun skim kredit yang mendukung pengembangan industri hilir karet.

e) Pembinaan petani dalam peningkatan teknik budidaya dan penerapan pasca panen yang lebih efisien.

f) Membangun jaringan kerjasama yang kuat antar pelaku usaha dalam bentuk model klaster industri.

g) Membangun kelembagaan keuangan mikro atau BUMD yang dapat berperan menggantikan peran tengkulak atau pedagang besar.

\section{Analisis Finansial}

Kelayakan usaha pengembangan agroindustri berbahan baku lateks kebun dalam kajian ini dilihat dari arus rugi laba perusahaan, serta analisis keuntungan dengan menggunakan indikator Benefit Cost (B/C) ratio, IRR, serta Nilai NPV dari arus dana selama 10 tahun. Asumsi yang digunakan dalam kajian ini adalah sebagai berikut:

a) Biaya amortisasi lahan dianggap tidak ada (Rp. 0,-).

b) Bangunan yang digunakan diasumsikan akan mampu berfungsi dengan baik selama 20 tahun.

c) Sentrifuse dan mesin lainnya diasumsikan dapat berfungsi selama 8-10 tahun, dengan demikian biaya penyusutan terhadap alat sentrifuse tersebut dikenakan sebesar $12,5 \%$.

d) Generator Listrik dianggap hanya dapat berfungsi dengan baik selama 3-4 Tahun. Dengan demikian biaya penyusutan terhadap alat ini dikenakan sebesar 33,33\% dari harga beli awal.

e) Peralatan kantor diasumsikan dapat digunakan dengan baik selama 4-5 tahun. Dengan demikian biaya penyusutan yang dikenakan terhadap perlengkapan kantor adalah sebesar 25 $\%$ per tahun.

f) Biaya tetap lainnya yang diperhitungkan dalam kajian ini adalah biaya provisi, asuransi bayar di muka, dan biaya tak terduga selama proses konstruksi industri. Biaya amortisasi untuk biaya provisi dan asuransi diperhitungkan sebesar 10\% per tahun.

g) Beban bank yakni berupa bunga atas pinjaman kredit yang dilakukan dibebankan sebesar $7,5 \%$ per tahun yang dibayarkan selama jangka waktu pinjaman yakni selama 10 tahun. Asumsi ini sejalan dengan kebijakan $\mathrm{pemerintah}$ yang masih mempertahankan BI rate sebesar 7,5\% pertahun.

h) Beban pajak dalam kajian ini mengacu pada perhitungan pajak penghasilan berdasarkan Undang-undang RI Nomor 17 tahun 2000 yakni sebagai berikut :
1. Laba sampai dengan Rp. 50.000.000,- $=10 \%$
2. Laba Rp. 50.000.000,-s/d Rp. $100.000 .000,-\quad=15 \%$
3. Laba di atas Rp. 100.000.000,- $=30 \%$

Dengan menggunakan berbagai asumsi penghitungan biaya dan penerimaan di atas maka perusahaan telah akan memperoleh penerimaan yang cukup untuk menutupi biaya operasional pada tahun ke4 dan keuntungan bersih yang cukup menutupi seluruh biaya (investasi dan operasional) pada tahun ke-8. Selanjutnya pada Tabel 3 berikut disajikan sejumlah indikator kelayakan pendirian industri lateks pekat di lokasi penelitian.

Pada Tabel 3 dapat dilihat baik indikator kelayakan usaha NPV, IRR dan $\mathrm{B} / \mathrm{C}$ ratio secara bersama-sama menunjukkan bahwa usaha pengolahan lateks pekat di lokasi penelitian adalah layak untuk dilaksanakan. Dapat dilihat bahwa dengan discount factor sebesar 7,5\% per tahun, usaha yang hendak dikembangkan mampu memberikan nilai bersih sebesar $\mathrm{Rp}$ 26.458.241 dalam kurun waktu 10 tahun. Kemampuan usaha pengolahan lateks pekat yang diusulkan mampu memberikan 
Tabel 3. Indikator kelayakan usaha industri lateks pekat di lokasi penelitian Table 3. Indicator feasibility of centrifuged latex in research location

\begin{tabular}{ccc}
\hline No & Indikator & Nilai \\
& Indicator & Value \\
\hline a) & NPV $(7,5 \%)$ & Rp. 26.458 .241 \\
b) & IRR (\%) & 12,99 \\
c) & B/C ratio & 1,40 \\
\hline
\end{tabular}

imbalan IRR sebesar 12,99\%. Kemampuan usaha tersebut memberikan keuntungan yang memadai dilihat dari nilai rasio benefit cost $(\mathrm{B} / \mathrm{C})$ sebesar 1,40 yang berarti selama kurun waktu 10 tahun, usaha tersebut mampu mengembalikan modal yang dicurahkan sebesar 1,4 kalinya.

\section{KESIMPULAN DAN SARAN}

\section{Kesimpulan}

1. Sebesar $78,33 \%$ responden petani setuju jika terdapat investor atau lembaga yang bersedia mendirikan industri hilir pengolahan karet alam di lokasi petani.

2. Sejumlah $62,00 \%$ responden petani menyatakan bahwa bahan baku lateks kebun akan dapat dengan mudah diperoleh jika industri pengolahan karet alam di dirikan di lokasi penelitian.

3. Sejumlah $60,00 \%$ responden petani menyatakan bersedia mengalihkan hasil produksi mereka dari bahan olahan karet kering (bokar) menjadi lateks kebun jika m e m a n a d a par yang membutuhkannya.

4. Hasil analisis finansial menunjukkan bahwa upaya pendirian dan pengembangan industri penghasil lateks pekat di lokasi penelitian secara ekonomi layak untuk dilakukan.

\section{Saran}

Hasil analisis lingstra menunjukkan bahwa agar pengembangan industri pengolahan karet berbasis lateks kebun dapat dilaksanakan di Provinsi Jambi maka disarankan untuk:

a) Menyusun roadmap pengembangan industri hilir karet skala rumah tangga yang diikuti dengan penyusunan model klaster pengembangan industri hilir karet di Provinsi Jambi. b) Membangun industri hilir karet sebagai model pengembangan yang ditunjang dengan pengadaan skim kredit yang mendukung pengembangan industri hilir karet serta membangun kelembagaan keuangan mikro atau BUMD yang dapat berperan menggantikan peran tengkulak atau pedagang besar.

c) Mencermati faktor lingkungan strategis berikat untuk membangun agroindustri hilir yaitu :

1. Penyediaan bahan baku

2. Kesiapan pelaku usaha

3. Terbatasnya dana dan penumpukan modal

4. Rendahnya tingkat produktivitas dan kualitas bokar

5. Dukungan kebijakan Pemerintah dan Pemerintah Daerah

6. Komitmen Pemerintah dan perbankan dalam penyediaan dana dengan biaya yang rendah

7. Terbukanya peluang pasar

8. Kuatnya keterikatan antara petani dan tengkulak

9. Kekuatan oligopsoni para pedagang besar (pemasok industri crumb rubber)

\section{DAFTAR PUSTAKA}

Alamsyah, Z., D. Napitupulu dan Elwamendri. 2011. Konstruksi Model Kemitraan Pemasaran Bahan Olah Karet (Bokar) Rakyat Di Provinsi Jambi. Prosiding Seminar Nasional Hasil Penelitian Dosen Pertanian Volume III. Jambi, 19 Februari. Universitas Jambi, .: 51-66.

Balai Penelitian Teknologi Karet (BPTK). 2003. Jok Sebutret, Produk Alternatif yang Prosfektif. Balai Penelitian Teknologi Karet, Bogor. 
Biro Pusat Statistik (BPS). 2010. Statistik Perkebunan Provinsi Jambi. Biro Pusat Statistik, Jambi.

Evawani, N. 2011. Analisis Strategi Peningkatan Mutu Bahan Olah Karet (Bokar) Di Provinsi Jambi. Tesis. Program Pasca Sarjana Universitas Jambi, Jambi.

Junaidi, 2009. Pola Kemitraan Pembangunan Perkebunan untuk Peningkatan Pendapatan Petani pada Era Otonomi Daerah di Kabupaten Bengkalis. web.ipb.ac.id., diakses tanggal 1 November 2013.
Saleh, D. 1991. Optimalisasi Produksi dan Pemasaran Karet Alam Indonesia dalam Dinamika Struktur Industri Karet Dunia. Disertasi. Fakultas Pascasarjana IPB. Bogor.

Suharyono, 2006. Peranan Petani dalam Adopsi Teknologi Budidaya Karet di Beberapa Sentra Produksi di Jambi. Sitgma XIV (1): 159-164. 